\title{
Evidence of Climate Change and Adaptation Strategies among Grain Farmers in Sokoto State, Nigeria
}

\author{
Ikpe Elisha ${ }^{1}$, Sawa B. A. ${ }^{1}$ and ${ }^{2}$ Ejeh Udeh Lawrence \\ ${ }^{1}$ Department Of Geography, Ahmadu Bello University, Zaria, Nigeria \\ ${ }^{2}$ Department Of Geography, Federal College Of Education, Zaria, Nigeria
}

\begin{abstract}
This study examined the evidence of climate change and adaptation strategies among grain farmers in Sokoto state. The paper focused at finding out the farmers' knowledge of climate change and adaptation strategies. Rainfall and temperature data for 30 years were sourced from the Sokoto Rima Basin Development Authority's Rainfall Reading Office, Goronyo and Nigerian Metrological Services (NIMET) Oshodi, Lagos and used for this study. Purposeful sampling technique was used in the selection of 385 respondents. Farmers' perception and adaptation strategies to climate change were obtained by means of structured questionnaire administered to the sampled grain farmers. The results were summarized by means of frequencies and percentages and presented in tabular forms, trend lines and bar charts. The study revealed that farmers' perceptions of climate change issues are in line with the analysed climate records for the area; the annual rainfall totals favour the cultivation of millet; there is late onset of rain and frequent agricultural drought which affects grain production in the area. The study recommends that the research institutes should produce better adapted varieties of millet and other grains and government should subsidize the seeds to the farmers. Furthermore, there should be adequate provision for irrigation, weather forecasting and other agricultural technological infrastructure, modern knowledge on climate change adaptation and strengthening of the extension services. The study concludes that the climatic characteristics of the study area affect grain production and that adaptation strategies have significant contribution on grain production in the area.
\end{abstract}

Keywords: Adaptation strategies, Climate Change, Evidence, Grain farmers and Sokoto state.

\section{Introduction}

Climate change has become the primary environmental threat of the 21st century. It is now on the global political agenda as never before. The Fourth Assessment Report of the Intergovernmental Panel on Climate Change (IPCC) affirms that climate change is no longer in doubt, IPCC(2007). Although extreme violent weather has occurred throughout history, recent upsurge in climate related hazards is confirming the argument for global warming and climate change, Odjugo and Ikhuoria (2003). The evolving climate change coupled with increasing temperature has been observed to plunge some localities. The IPCC (2001) projected that climate change resulting from increased greenhouse gases concentrations has the potential to harm societies and ecosystems, agriculture and forestry, water resources etc. All stages of agricultural production from land clearing and preparation, through crop growth and management to harvesting, storage, transportation, and marketing of agricultural products are subject to the influence of weather and climate.Societies have a long record of managing the impacts of weather and climate related events. Thus, this research focussed on recognising the evidence of climate change in the study area and the grain farmers' adaptation strategies to climate change.

\subsection{Meaning and Causes of Climate Change}

\section{Literature Review}

Climate change is a change in the state of the climate that can be identified (e.g. by using statistical tests) by changes in the mean and/or the variability of its properties, which persists for an extended period typically decades or longer, IPCC (2007). Climate change, in the most general sense -encompasses all forms of climatic inconstancy (that is, any differences between the "long-term" statistics of the meteorological elements calculated for different periods but relating to the same area), regardless of their statistical nature or physical cause, Maunder(1994). Climate change implies a new mean climatic state or climatic normal, Ayoade(2003). The most crucial things about the concept of climate change is not only the time periods involved but also the degree of variability that the change is subjected to as well as the duration and impact of such variability on man and the ecosystem.

Climate change is caused by two basic factors namely natural processes (biogeographical) and human activities (anthropogenic). The natural processes are the astronomical and extraterrestrial factors. The astronomical factors are the eccentricity of earth's orbit, obliquity of ecliptic and orbital procession. The extraterrestrial factors include solar radiation quantity (sunspot) and quality (ultra violet radiation change). A 
high solar quality and quantity and period of perihelion (when the earth is nearest to the sun), result in heating up of the earth surface which lead to global warming. Volcanic eruptions also lead to both global warming and cooling. Through volcanic eruptions, lot of gases, vapour and particulate matter are emitted into the atmosphere. Such emissions influence the atmospheric chemistry thereby creating short -term cooling and long- term heating of the atmosphere. Prominent examples of such eruptions of great magnitude were Krakatoa eruption in 1883, Mount Agung in 1963, Mount Pinatubo in 1992 and Republic of Iceland in 2011.Researchers (Buba, 2004; Porbeni, 2004; DeWeerdt, 2007 and Odjugo, 2007) have shown that for the past few decades, anthropogenic factors like transportation, industrialization, urbanization, burning of fossil fuel, agriculture, water pollution, changes in land cover and deforestation among others are the major contributing factors to the depletion of the ozone layer and its associated global warming and climate change. Man is at the centre of climate change through activities that add to the amount of greenhouse gases in the atmosphere, Akpodiogaga and Odjugo (2010).

\subsection{Meaning of Adaptation}

The IPCC (2007) defines adaptation as the "adjustment in natural or human systems to a new or changing environment". Adaptation to climate change is a process through which people reduce the adverse effects of climate on their health and well-being and take advantage of opportunities that the environment provides, Saka (2008). Various types of adaptation can be distinguished, including anticipatory and reactive adaptation, private and public adaptation, and autonomous and planned adaptations.

\subsection{Evidence of Climate Change in Nigeria}

Reports from recent literature point to climate change in Nigeria. Ahmad and Ahmed (1999), IPCC (2001), Nigerian Environmental Study/Action Team (NEST, 2003) and Hengeveld and Fergusson (2005) provided indicators that one could use to assess the evidence of climate change in a region. These include increasing temperature, increasing evapotranspiration, decreasing rainfall amount in the continental interiors, increasing rainfall in the coastal areas, increasing disruption in climate patterns and increasing frequency and intensity of unusual or extreme weather related events such as; thunderstorms, lightning, landslides, floods, droughts, bush fires, unpredictable rainfall patterns, sea level rise, increase desertification and land degradation, drying up of rivers and lakes and constant loss of forest cover and biodiversity.A further support of the evidence of climate change in Nigeria by Odjugo $(2005 ; 2009)$ is the increase in rainfall amount in the coastal areas since the 1970s, and a constant decline in rainfall amount and duration in the continental interior of the semi-arid region of Nigeria. The increasing temperature and decreasing rainfall in the semi-arid region of Northern Nigeria- Sokoto, Katsina, Kano, Nguru and Maiduguri may have resulted in the increasing evapotranspiration, drought and desertification in the region as reported by Odjugo and Ikhuoria(2003) and Adefolalu(2007). Constant loss of forest cover and biodiversity in Nigeria is linked to global warming and climate change, NEST(2003); Ayubaet al., (2007).

The increasing temperature and decreasing rainfall have led to frequent drought and desertification. The Sahara desert is observed to be expanding to all directions trying to engulf the Sahellian region of Africa with annual expansion of 1-10 km, Odjugo and Ikhuoria(2003); Yaqub (2007). Odjugo and Ikhuoria (2003) also observed that Nigeria north of $12^{\circ} \mathrm{N}$ is under severe threat of desert encroachment and sand dunes are now common features of desertification in states like Yobe, Borno, Sokoto, Jigawa and Katsina. The migrating sand dunes have buried large expanse of arable lands, thus reducing viable agricultural lands and crops' production. This has prompted massive emigration and resettlement of people to areas less threatened by desertification. Such emigration gives rise to social effects like loss of dignity and social values. It often results in increasing spate of communal clashes among herdsmen and farmers and such clashes resulted in the death of 186 people in six northern states of Nigeria between 1998 and 2006, Yugunda(2002); Yaqub (2007).

In Nigeria, many rivers have been reported to have dried up or are becoming more seasonal, while Lake Chad has shrunk in area from 22,902 $\mathrm{km}^{2}$ in 1963 to a mere $1304 \mathrm{~km}^{2}$ in 2000 . This shows that what is left of Lake Chad in the year 2000 is just 5.7\% of 1963, Odjugo (2007). Awake, (2009) also confirms the fact that Lake Chad has shrunk by $95 \%$ since the 1960s. Lake Chad and so many rivers in Nigeria, especially in Northern Nigeria, are in the danger of disappearing. Available evidence also shows that climate change has impacted on agriculture and health in Nigeria, Mshelia (2005); Adefolalu (2007).

Already, Nigerian urban centers have been feeling the impacts of climate change with incessant annual flooding that affect large areas and large number of people. For example, in 2010, flood in Northern Nigeria affected 2 million people in Jigawa State and another 40, 000 people were displaced in Sokoto State where Usmanu Dan Fodio University was forced to close down for weeks as a result of bridge collapse associated with the flood. Similar floods were reported in Lagos where 689 people were to be relocated in Ajegunle as a result of flood, Yekken (2011). 


\subsection{Agriculture and Climate Change}

Agriculture is perhaps the most sensitive to climate change related issues of all human economic activities. Changes in the world's climate will bring major shifts in food production. In spite of recent technological and scientific development, weather remains a key variable in agricultural production. Weather and climate affect agriculture and determine the adequacy of food supplies. Climate determines whether or not rainfed agriculture will be successfully cultivated in a given area. Weather and climate act both as a resource and a constraint to agricultural production. The resource value of weather has to be optimized while the hazards posed by weather have to be managed, Ayoade (2002). It is common knowledge that farmers in Sub-Saharan Africa, including Nigeria are struggling to cope with the current climate variability, Chakeredzaet al(2009).

\subsection{Study Area}

\section{Methodology}

Goronyo is a local government area (LGA) in Sokoto state, Nigeria. It is located along Latitude $13^{\circ}$ $27^{\prime} 11^{\prime \prime}$ North and Longitude $05^{\circ} 40^{\prime} 35^{\prime \prime}$. Its headquarters is at Goronyo, on the bank of the Sokoto River. It has an area of $1,704 \mathrm{~km}^{2}$. Goronyo is in the dry Sahel, surrounded by sandy savanna and isolated hills. With an annual average temperature of $28.3^{\circ} \mathrm{C}$, Goronyo, on the whole is a very hot area. However, maximum daytime temperatures are for most of the year generally under $40^{\circ} \mathrm{C}$ and the dryness makes the heat bearable. The hottest months are February to April when daytime temperatures can exceed $45^{\circ} \mathrm{C}$. The rainy season is from June to October. The annual rainfall is between $500 \mathrm{~mm}$ in the north and $800 \mathrm{~mm}$ to the south. The area's lifeline for growing crops is the floodplains of the Goronyo dam system which are covered with rich alluvial soil, Sani(2005).Goronyo is essentially an agricultural area with traditional mode of production predominating with more than 90 percent of the population engaged in subsistence farming. The main crops produced in the LGA are millet, guinea corn, maize, rice, beans etc.

Climatic data used in this study are daily rainfall and temperature records of Goronyo (1981-2010), and Goronyo's grain farmers' perception and adaptation to climate change. The grain farmers' perception helped to know the sensitivity of farmers to the changing climate and their adaptive strategies to climate change. The daily rainfall and temperature records for the stated period were obtained from the Sokoto Rima Basin Development Authority, rainfall reading office, Goronyo, and Nigerian Meteorological Services (NIMET), Oshodi, Lagos. While farmers' perception and adaptation strategies to climate change were obtained by means of structured questionnaire.

\subsection{Materials for the Study}

The respondents for the questionnaire were the grain (sorghum, millet and maize) farmers in the eleven (11) wards in the LGA. The number of questionnaire used was based on the population of the study area. To determine the sample size for this study, Krejcie and Morgan's (1970) method of determining sample size was adopted which states that, for an area with a population between $75,000-999,999$, the sample size to be used is 382. Since the population of the study area is 182,296 which fall between these ranges, the sample size of 382 is in order. However, 385 respondents were used to have equal representation in each ward, but only 382 were returned.

\subsection{Sampling Technique}

Purposeful sampling technique was used to determine the respondents afterwhich simple random sampling was used to administer the questionnaire among the eleven wards of the LGA. Purposeful sampling, according to Bernard (2002) "is the deliberate choice of an informant due to the quality the informant possesses." The three hundred and eighty five (385) questionnaires were shared proportional to the population of each ward, but due to the non-availability of population figures for each ward from the 1991 and 2006 census results, the questionnaire was distributed equally among the eleven (11) wards, with 35 questionnaires in each ward. For the purpose of administering the questionnaire, grain farmers above thirty (30) years of age and who must have lived at least twenty (20) years within the study area were identified through the "SarkinNoma" (Head of the Farmers) and the village Heads. This was done by asking the farmers of their age and how long they have lived in the area. Thereafter the questionnaire was issued. The reason for this decision was that those within the age bracket have the information needed about climate change. The researcher was assisted by field assistants.

To present the various agricultural adaptive strategies used by the farmers to cope with climate change, percentage analysis was used. The data was summarized and presented in tables, charts, percentages. 
IV. Findings And Discussion

Table 1: Rainfall and Temperature Characteristics of Goronyo, $1981-2010$

\begin{tabular}{|c|c|c|c|c|c|c|c|}
\hline Years & $\begin{array}{c}\text { Total Annual } \\
\text { Rainfall } \\
\text { (mm) }\end{array}$ & $\begin{array}{c}\text { Total Annual } \\
\text { Number of } \\
\text { Rain Days }\end{array}$ & $\begin{array}{l}\text { Onset } \\
\text { Dates }\end{array}$ & $\begin{array}{c}\text { Cessation } \\
\text { Dates }\end{array}$ & $\begin{array}{c}\text { Annual Length } \\
\text { of Rainy Season } \\
\text { (days) }\end{array}$ & $\begin{array}{c}\text { Mean Max. } \\
\text { Temperature } \\
\left({ }^{\circ} \mathrm{C}\right)\end{array}$ & $\begin{array}{c}\text { Mean Min. } \\
\text { Temperatu } \\
\text { re }\left({ }^{\circ} \mathrm{C}\right)\end{array}$ \\
\hline 1981 & 556.9 & 21 & $20^{\text {th }}$ May & $30^{\text {th }}$ Sept. & 133 & 34.8 & 21.5 \\
\hline 1982 & 519.7 & 18 & $20^{\text {th }}$ May & $31^{\text {st }}$ Oct. & 164 & 35 & 22.1 \\
\hline 1983 & 620.7 & 20 & $31^{\text {st }}$ March & $20^{\text {th }}$ Sept. & 173 & 35.4 & 22.5 \\
\hline 1984 & 263.4 & 12 & $10^{\text {th }}$ May & $5^{\text {th }}$ Oct. & 148 & 35.7 & 22.8 \\
\hline 1985 & 434.8 & 22 & $15^{\text {th }}$ May & $30^{\text {th }}$ Sept. & 138 & 35 & 22.9 \\
\hline 1986 & 439.4 & 19 & $31^{\text {st }}$ May & $5^{\text {th }}$ Nov. & 158 & 35.2 & 23.1 \\
\hline 1987 & 285.77 & 24 & $15^{\text {th }}$ May & $30^{\text {th }}$ Sept. & 138 & 36.1 & 22.2 \\
\hline 1988 & 520.6 & 16 & $5^{\text {th }}$ June & $5^{\text {th }}$ Sept. & 92 & 35 & 22.9 \\
\hline 1989 & 376.5 & 16 & $15^{\text {th }}$ June & $20^{\text {th }}$ Sept. & 97 & 34.3 & 22 \\
\hline 1990 & 508.7 & 20 & $10^{\text {th }}$ May & $5^{\text {th }}$ Oct. & 148 & 35.5 & 22.9 \\
\hline 1991 & 480.64 & 23 & $30^{\text {th }}$ April & $10^{\text {th }}$ Oct. & 163 & 35 & 22.8 \\
\hline 1992 & 423.26 & 18 & $15^{\text {th }}$ May & $15^{\text {th }}$ Oct. & 153 & 34.1 & 22.3 \\
\hline 1993 & 397.3 & 18 & $25^{\text {th }}$ May & $30^{\text {th }}$ Sept. & 128 & 35.4 & 22.6 \\
\hline 1994 & 905.2 & 22 & $5^{\text {th }}$ June & $25^{\text {th }}$ Oct. & 142 & 35.1 & 22.7 \\
\hline 1995 & 336.8 & 18 & $25^{\text {th }}$ April & $30^{\text {th }}$ Sept. & 158 & 36 & 22.5 \\
\hline 1996 & 692.25 & 22 & $30^{\text {th }}$ April & $20^{\text {th }}$ Sept. & 143 & 36 & 21.8 \\
\hline 1997 & 641 & 30 & $25^{\text {th }}$ April & $31^{\text {st }}$ Oct. & 189 & 38.9 & 22.2 \\
\hline 1998 & 658.5 & 19 & $25^{\text {th }}$ April & $25^{\text {th }}$ Sept. & 153 & 35.7 & 23.1 \\
\hline 1999 & 592 & 21 & $5^{\text {th }}$ June & $10^{\text {th }}$ Oct. & 127 & 35.5 & 22.4 \\
\hline 2000 & 407.7 & 18 & $15^{\text {th }}$ June & $15^{\text {th }}$ Oct. & 122 & 34.9 & 22.1 \\
\hline 2001 & 721.7 & 22 & $20^{\text {th }}$ April & $25^{\text {th }}$ Sept. & 158 & 35.5 & 22.6 \\
\hline 2002 & 568.5 & 21 & $5^{\text {th }}$ June & $20^{\text {th }}$ Oct. & 137 & 35.8 & 22.7 \\
\hline 2003 & 344.14 & 14 & $20^{\text {th }}$ April & $30^{\text {th }}$ Sept. & 163 & 32.4 & 22.8 \\
\hline 2004 & 649.5 & 25 & $30^{\text {th }}$ April & $5^{\text {th }}$ Oct. & 158 & 36.4 & 22.5 \\
\hline 2005 & 609.2 & 26 & $5^{\text {th }}$ May & $10^{\text {th }}$ Oct. & 158 & 36 & 23.1 \\
\hline 2006 & 740 & 24 & $20^{\text {th }}$ May & $5^{\text {th }}$ Oct. & 138 & 35.9 & 22.8 \\
\hline 2007 & 636.4 & 25 & $10^{\text {th }}$ April & $25^{\text {th }}$ Sept. & 199 & 35.9 & 23.3 \\
\hline 2008 & 514.6 & 30 & $30^{\text {th }}$ April & $10^{\text {th }}$ Oct. & 163 & 32.1 & 22.7 \\
\hline 2009 & 567.3 & 28 & $5^{\text {th }}$ May & $5^{\text {th }}$ Nov. & 184 & 36.5 & 23.9 \\
\hline 2010 & $1,496.5$ & 24 & $5^{\text {th }}$ June & $31^{\text {st }}$ Oct. & 148 & 36 & 23.1 \\
\hline Mean & 563.6 & 21 & $11^{\text {th }}$ May & $7^{\text {th }}$ Oct. & 149 & $35.4^{\circ} \mathrm{C}$ & $22.6^{\circ} \mathrm{C}$ \\
\hline
\end{tabular}

(Source, Field survey 2012)

\subsection{Onset Dates of the rains in Goronyo}

The linear trend and trend line equation for the onset dates of the rainy season in the study area are shown in fig.2. It clearly indicates a decreasing trend in the onset dates (that is, the rains are now coming late). The earliest onset date of rain in the study area within the 30 years of study as shown in table 2 is $31^{\text {st }}$ March, (1983). While the late onset date within the 30 years of study is $15^{\text {th }}$ June. The mean onset dates within the thirty years of the study is $11^{\text {th }}$ May.

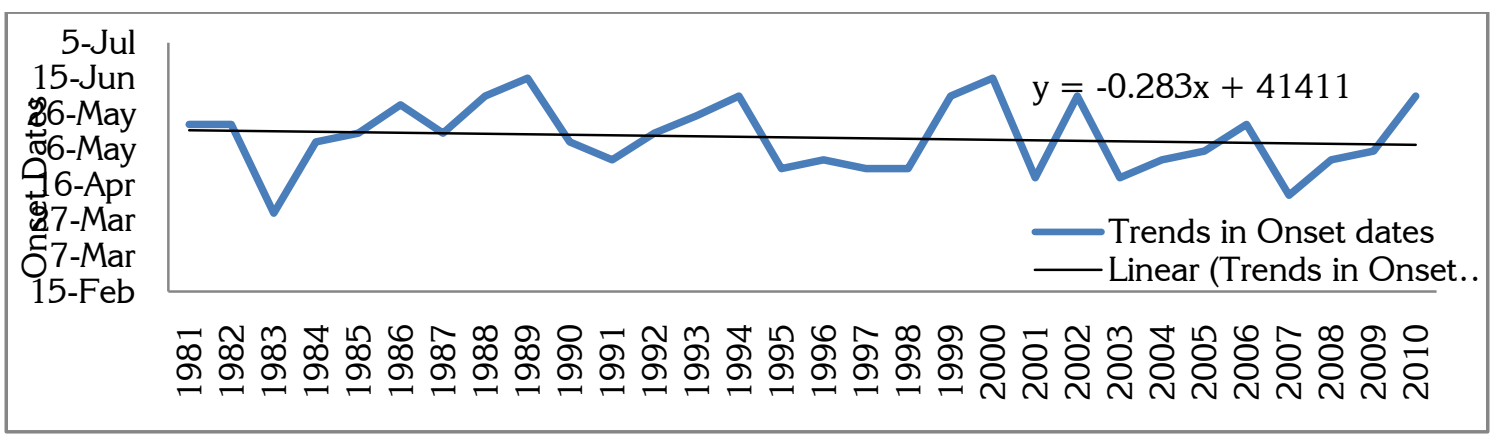

Fig. 2: Trends in Rainfall Onset Dates at Goronyo (1981 - 2010)

Source: Field work, August 2012

\subsection{Cessation Dates}

The earliest cessation date in Goronyo occurred on $5^{\text {th }}$ September (1984), while the latest cessation date occurred (twice within the 30 years of study) on $5^{\text {th }}$ November (1986 and 2009). The average cessation date of rainfall in Goronyo within the thirty years of study is $7^{\text {th }}$ October. As shown in table 1 , cessation dates in the study area within the 30 years of study occur between $5^{\text {th }}$ September and $5^{\text {th }}$ November. These periods of anomalies, that is early cessation may affect the production of grains in the study area. 


\subsection{Length of Rainy Season}

The linear trend and trend line equation for the length of rainy season is shown in figure 3 . From this figure, it is observed that the trend line for the length of rainy season is increasing. The linear trend line equation for the length of rainy season is $y=0.858 x+135.5$. This positive trend line equation further indicates that the length of the rainy season is on the increase in Goronyo. The highest length of rainy season within the 30 years of study was recorded in 2007 (199 days out of the 365 days of that year), while the shortest length of rainy season was recorded in 1988, with 92 days. The mean length of rainy season (days) is 149 days.

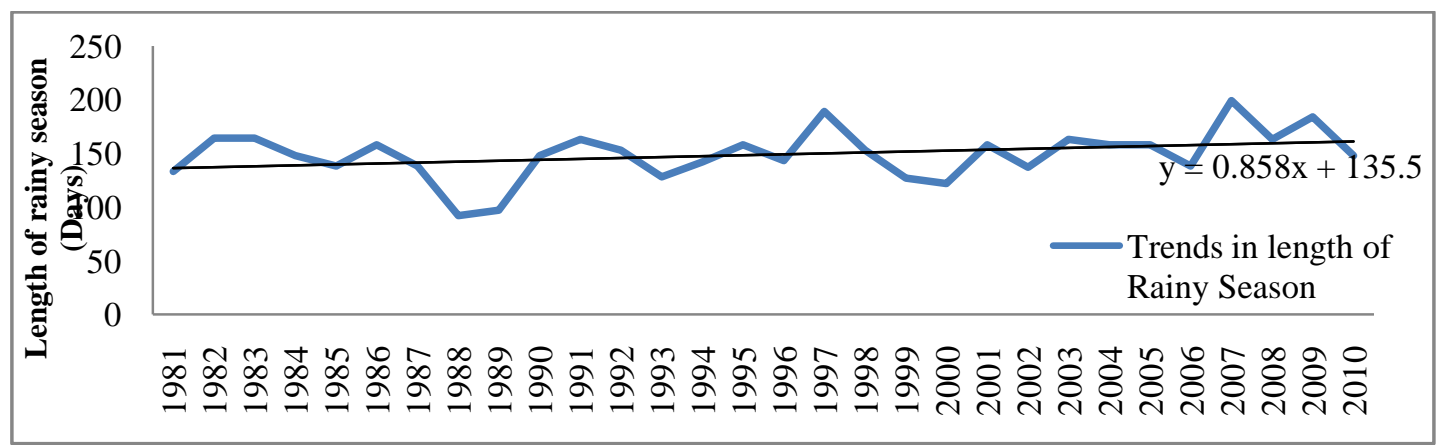

Fig. 3: Trend in Length of Rainy Season at Goronyo (1981 - 2010)

Source: Field survey, August 2012

\subsection{Number of Rainy Days}

Table 1 indicated an upward trend in the number of rainy days. The annual number of rainy days in Goronyo ranges between (12-30 days). The highest annual total number of rain days is 30 days and was recorded in 1997 and 2008. While the lowest number (12 days) occurs in 1994. The mean annual number of rainy days in the study area is 21 days. Researches shows that millet requires the minimum of 60-70 days of rain for effective cultivation and yield, sorghum requires 80 rainy days and maize 80-100 rainy days. Going by the records of rainy days presented in table 1 ,

The length of the rainy season in Goronyo may not favour the cultivation of crops having tap root system such as millet, sorghum and maize. Hence, the need for an adaptive strategy to climate change scenarios in Goronyo. Amongst the three crops- millet, sorghum and maize, the number of rainy days pattern in Goronyo favours millet production most. This is why millet remains the favourite crop and most cultivated among the grain farmers in Goronyo because characteristically, millet is better adapted than most other crops to dry infertile soils, high temperatures, low and erratic precipitation, short growing seasons and acidic soils with poor water-holding capacity.

4.5 Annual Rainfall

Trends in the total annual rainfall of Goronyo for the period of thirty years are presented in figure 4

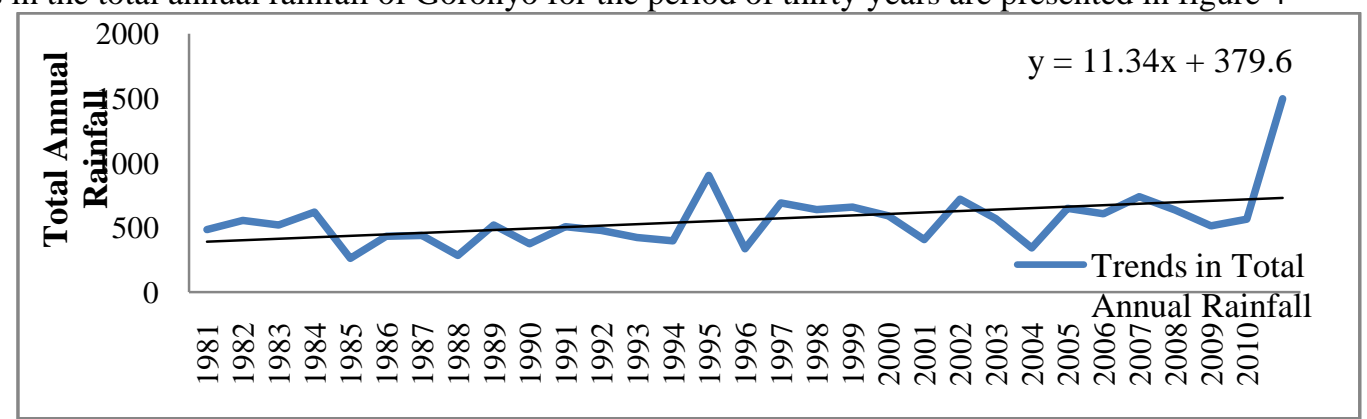

Fig. 4: Trends in Total Annual Rainfall (mm) at Goronyo (1981 - 2010)

Source: Field survey, August 2012

The trends in fig. 4 show an increasing annual rainfall amount. The best fit trend line equation is $\mathrm{y}=$ $11.34 \mathrm{x}+379.6$. The positive equation implies that annual rainfall is on the increase. More so, in table 1 the highest rainfall was recorded in $2010(1,496.5 \mathrm{~mm})$, while 1984 had the least rainfall $(263.4 \mathrm{~mm})$. The mean annual rainfall during the period of the study is $563.6 \mathrm{~mm}$. This amount is lower than the minimum required for the cultivation of sorghum and maize in the study area. Millet requires the minimum of $300 \mathrm{~mm}$ of rainfall, sorghum 400-600 and maize 500-750mm. It then implies that millet yield was low in the years where annual rainfall was 300mm. Following the annual rainfall record in table 1, 1984 and 1987 are bad years for millet 
production as the annual total was less than $300 \mathrm{~mm}$ for millet production. While 1984, 1987, 1989, 1993, 1995 and 2003 were bad years for sorghum and maize production.

4.6 Major Adaptation Strategies to Climate Change by Farmers

It is no doubt that adaptation strategies can reduce the impacts of climate change and increase benefits. As shown in figure 6, crop rotation, mixed cropping, use of improved seed varieties, shifting cultivation, access to water for irrigation, use of organic and inorganic fertilizer, access to credit loan are the major adaptation strategies to climate change adopted by farmers in Goronyo.

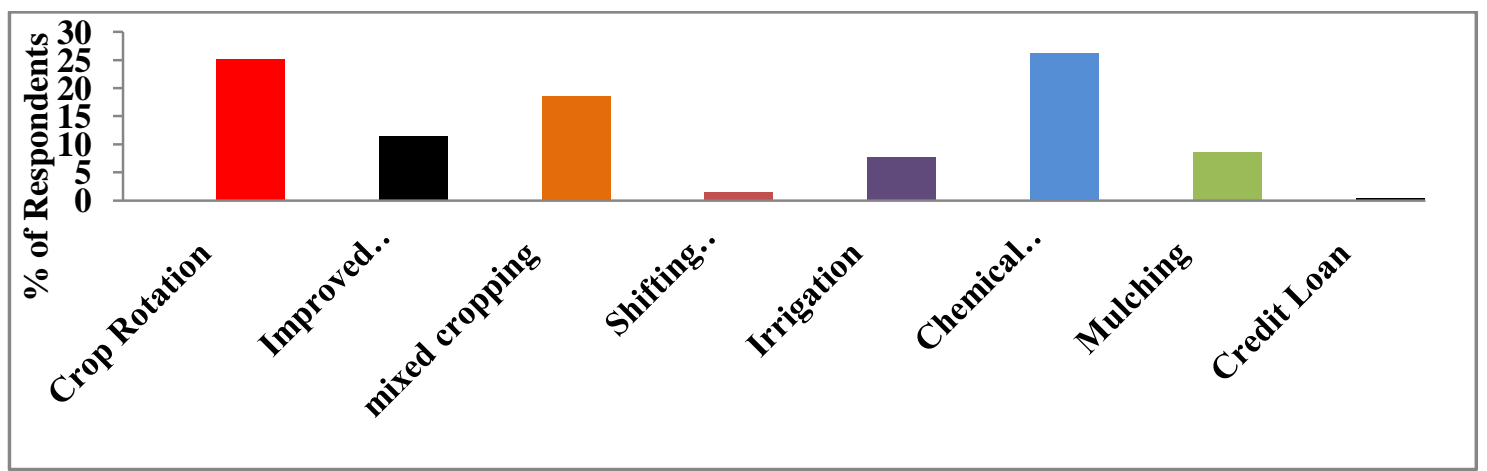

Fig. 5: Farmers' Strategies to Adapting to Climate Change in Grain Production

Source: Field survey, August 2012.

The questionnaire administered on the grain farmers contained a list of adaptation options for the farmers to choose from and then open ended questions for the farmers to itemize other viable adaptation strategies in the study area. The questionnaire was uniformly applied in the eleven wards of the study area. As strategies to adapting to climate change in grain production, $25.2 \%$ of the farmers practice crop rotation; $18.6 \%$ practice mixed cropping; 15.5 percent uses improved seed varieties; 1.5 percent use shifting cultivation; 7.8 percent use irrigation/fadama farming; $32.2 \%$ use chemical fertilizer (chemical fertilizer helps to improve crop yield); 3 percent use mulching with crop residue and animal dung; 0.2 percent use credit loan as a means of diversification of the economy for livelihood and only 0.5 percent stated that no adaptation method is best fit.

\section{Conclusion Of The Study}

The study has achieved to a reasonable extent the aim of carrying out this study on the evidence of climate change and adaptation strategies among grain farmers in Goronyo LGA of Sokoto state. Over the 30 years examined, rainfall is characterized by large inter-annual variability. The annual total rainfall favours the cultivation of millet than sorghum and maize. In addition, the study also revealed that the length of the rainy season in Goronyo is too short for the effective cultivation of grains without employing adaptive strategies. Summarily, the characteristics of rainfall and temperature in the study area are not consistent.Major Adaptation strategies of farmers in Goronyo are: Crop rotation, mixed cropping, use of improved seed varieties, shifting cultivation, intensification of irrigation or fadama farming and use of organic and inorganic manure among others. The study also showed that a decrease in rainfall is likely to push farmers to delay their planting dates. Factors that enhances the farmers' adaptive capacity to climate change includes: the farmers' farming experience, the farmers' ability to perceive changes to weather and climate indices, access to credit loan etc.

\section{Recommendations}

Following the findings made in the study within the 30 years covered, the following recommendations are made:

1. Since the annual rainfall totals favours the cultivation of millet, grain farmers should focus more on millet cultivation so as to maximize millet yield in the area.

2. Grain farmers should adopt viable adaptation strategies such as: improved seed varieties, Irrigation farming (since the study area is close to the Goronyo dam), credit loan, mixed cropping, crop rotation, shifting cultivationetc

3. Government policies should therefore ensure that farmers have access to improved seed varieties, chemical fertilizer, water for irrigation and affordable credit as these increases the resilience of farmers to climate variability.

4. The Goronyo dam should be developed and opened up for farmers' use as most of the farming activities in the study area is carried out around the Goronyo dam area, mostly maize cultivation. 


\section{References}

[1]. IPCC, Climate Change 2007: Impacts, adaptation and vulnerability. Contribution of working group II to the fourth assessment report of the Intergovernmental Panel on Climate Change (Parry, Martin L., Canziani, Osvaldo F., Palutikof, Jean P.,Vander Linden, Paul J., and Hanson, Clair E. (eds.)) Cambridge University Press, Cambridge, U.K (2007).

[2]. P Odjugo, P. and A Ikhuoria,The impacts of climate change and anthropogenic factors on desertification in the semi-arid region of Nigeria, Global Journal of Environmental Science, 2(2),2003, 118-126

[3]. IPCC, The report of working group II of the intergovernmental panel on climate change survey for policymakers. IPCC, 2001,879 $-884$

[4]. W.J. Maunder, Dictionary of global climate change ( $2^{\text {nd }}$ edn) (Chapman and Hall publishers: New York, 1994).

[5]. J.O. Ayoade, Introduction to agroclimatology (Ibadan: Vantage Publishers, 2003). (201)

[6]. A Buba, Climate change and water problems in Chad Republic, Journal of Arid Environment

[7]. 3(2), 2004, 42-50.

[8]. C Porbeni, The impacts of global warming on high latitudes and altitudes, Journal of Arid Environ., 3(2), 2004, 75-88.

[9]. S Deweerdt, Climate change coming home: global warming effects on population. World watch 20(3), 2007, 8-13.

[10]. P Odjugo, The impacts of climate change on water resources: global and regional analysis, Indonesian Journal of Geography, 39 (1), 2007, 23-41.

[11]. P Akpodiogaga and O. Odjugo, General overview of climate change impacts in Nigeria, Journal of Human Ecology, 29(1), 2010, 47-55. (1)

[12]. ASaka, Global warming and the impacts of climate change on vulnerable communities and sectors of economic growth.Atutorial review, Proc. $2^{\text {nd }}$ ANAFE International Symposium on Mainstreaming Climate Change into Agricultural and Natural Resources Management Education: Tools, Experiences and Challenges, Lilongwe, Malawi, 2008, 2-10.

[13]. Q.K. Ahmad and A. U. Ahmed, Social sustainability, indicators and climate change. A tutorial review, Proc. of the IPCC expert meeting, Colombo, Sri Lanka, 1999, 149 27-29

[14]. Nigerian Environmental Study/Action Team (NEST),Climate change in Nigeria: a communication guide for reporters and educators (Ibadan: NEST publishers, 2003).

[15]. H.W. Hengeveld and B.A Fergusson, An introduction to climate change: A Canadian perspective. (Canada: Environment Canada, 2005) 7-27.

[16]. P A Odjugo,An analysis of rainfall pattern in Nigeria, Global Journal of EnvironmentalScience, 4(2), 2005 139-145.

[17]. P.A. Odjugo, Global and regional analysis of the causes and rate of climate change. A tutorial review, Proc. National Conference on Climate Change and Nigerian Environment, Department of Geography, University of Nsukka, Nsukka, Nigeria, 29th June - 2nd July, 2009.

[18]. D Adefolalu, Further aspect of sahelian drought as evident from rainfall regime of Nigeria, Journal of Arch Meteorological Geography Biol. 13(1),1986, $277-295$.

[19]. H Ayuba, UMaryah and DGwary, Climate change impact on plant species composition in six semi-arid rangelands of Northern Nigeria, Nigerian Geographical Journal, 5(1), 2007, 35-42.

[20]. C N Yaqub, Desert encroachment in Africa: extent, causes and impacts, Journal of Arid Environment, 4(1), 2007, 14-20.

[21]. BS Yugunda, Socio-economic and cultural impacts of desert encroachment in Nigeria,

[22]. Journal of Environmental Dynamics, 5(2)2002, 19-30.

[23]. Awake, Are we running out of water? (Lagos, Nig.: Awake Publishers, 2009). (1) 3-7.

[24]. AD Mshelia,Adaptation strategies to climate change, Journal of Energy and Environment, 18 (3), $2005,74-81$.

[25]. S Yekken, Innovative spatial planning in mitigating climate change-related vulnerability in Nigerian urban. A tutorial review, Proc. Federal University of Technology, Minna, Nigeria, 2011, 2-10

[26]. S. Chakereddza, B. August, Y. Aissetou, S. Makungwa and D.K Saka, Mainstreaming climate change into agricultural education: challenges and perspectives (Nairobi, Kenya: World Agroforestry Centre publishers, 2009).

[27]. M. Sani, The geographical study of Sokoto central market, masters thesis,UsmanuDanfodio University, Sokoto, 2005.

[28]. R. Krejcie and D. Morgan, Determining sample size for research activities, Journal of Educational and Psychological Measurement (1), 1970, 607-610

[29]. H.R Bernard, Research methods in anthropology qualitative and quantitative methods (California: AltaMira Press, 2002) (3) 